\title{
Membangun loyalitas pelanggan melalui kualitas produk dan citra merek (studi pada pelanggan Oppo Jambi)
}

\author{
Resi Afrida*; Syahmardi Yacob; Novita Sari \\ Program Studi Manajemen Fakultas Ekonomi dan Bisnis Universitas Jambi \\ *E-mail korespondensi:resiafrida@gmail.com
}

\begin{abstract}
This study aims to analyze the quality of products and brand image of customer loyalty either partially or simultaneously. The number of samples in this study was 99 respondents. The type of research used is explanatory research while hypothesizing using multiple linear regression. Customer loyalty is influenced by brand image through product quality. However, other factors that influence customer loyalty and brand image, and product quality need to be continued by further research to increase customer loyalty from different perspectives.
\end{abstract}

Keywords: product quality, brand image, customer loyalty.

\begin{abstract}
Abstrak
Penelitian ini bertujuan untuk menganalisis kualitas produk dan citra merek terhadap loyalitas pelanggan baik secara parsial maupun secara simultan. Jumlah sampel dalam penelitian ini 99 responden. Jenis penelitian yang digunakan adalah explanatory research. Sedangkan untuk melakukan pengujian hipotesis menggunakan persamaan regresi linear berganda. Loyalitas pelanggan dipengaruhi citra merek melalui kualitas produk namun demikian, terdapat juga faktor lain yang mempengaruhi loyalitas pelanggan selain citra merek dan kualitas produk yang perlu dilanjutkan oleh penelitian lain untuk meningkatkan loyalitas pelanggan dari perspektif yang berbeda.
\end{abstract}

Kata kunci: Kualitas produk, citra merek, dan loyalitas pelanggan.

\section{PENDAHULUAN}

Hingga tahun 2000an dunia dipenuhi dengan tumbuh pesatnya industri telekomunikasi yang menjadi cermin dari ketat dan tingginya kebutuhan akan infomasi yang mudah diakses oleh masyarakat. Smartphone merupakan salah satu teknologi yang berkembang dengan cepat dari tahun ke tahun. Banyak bermunculan merek-merek baru di dunia persaingan Telepon Seluler yang saling berlomba untuk menciptakan produk unggulan mereka. Produsen dituntut untuk tidak hanya sekedar menciptakan produk tetapi juga harus memahami keinginan dan kebutuhan konsumen. Hal tersebut dibutuhkan produsen untuk mampu bersaing dengan produsen lain.

Untuk mencapai hal tersebut perusahaan membutuhkan pelanggan yang lebih banyak ketimbang yang dimiliki oleh pesaing. Namun sekedar memiliki pelanggan saja tidaklah cukup, karena pelanggan tersebut haruslah loyal terhadap produk, sehingga dapat lebih memastikan keberlangsungan perusahaan tersebut.

Loyalitas merupakan asset yang sangat berharga bagi setiap perusahaan karena dengan menjadi pelanggan yang loyal mereka memiliki komitmen terhadap merek yang kemudian akan mendatangkan profit bagi perusahaan. Selain itu juga dalam jangka panjang, menjaga pelangga lama lebih mudah ketimbang mencari dan mendapatkan 
pelanggan baru. Pelanggan yang loyal menurut Griffin, J (2005) melakukan pembelian ulang, membeli dari berbagai lini produk dari suatu merek yang sama, merekomendasikan merek tersebut kepada orang lain, dan juga memiliki kekebalan terhadap penawaran produk pesaing.

Salah satu cara yang efektif untuk dapat mencapai loyalitas pelanggan adalah dengan memberikan kualitas produk yang baik. hal ini dikemukakan oleh oleh Fauzi'ah, S (2014) yang menyebutkan kualitas yang baik memungkinkan adanya kepuasan konsumen dan akan menarik konsumen baru, sehingga diharapkan akan membuat konsumen loyal pada akhirnya.

Selain memberikan kualitas produk yang baik untuk dapat mempertahan loyalitas pelanggan, cara lain untuk meraih keunggulan kompetisi dan mempertahankan loyalitas pelanggan adalah dengan membentuk citra merek yang positif dimata pelanggan. Karena semakin baik citra suatu merek dalam benak konsumen maka akan membuat konsumen memiliki ciri-ciri pelanggan yang loyal (Griffin, J., 2005). Selain itu Rangkuti, F (2002) mengatakan apabila konsumen beranggapan bahwa merek tertentu secara fisik berbeda dari merek pesaing, citra merek tersebut akan melekat secara terus menerus sehingga dapat membentuk kesetiaan merek tertentu yang disebut dengan loyalitas merek.

Berangkat dari fenomena yang telah dikemukakan, maka menimbulkan ketertarikan untuk mengangkat tema ini menjadi suatu kajian empirik dengan judul "Membangun Loyalitas Pelanggan Melalui Kualitas Produk dan Citra Merek (Studi pada Pelanggan OPPO Kota Jambi)".

\section{TINJAUAN PUSTAKA}

\section{Landasan teori}

Kualitas produk merupakan faktor penting yang mempengaruhi kinerja jangka panjang suatu unis bisnis. Menurut Tjiptono, F., Chandra, G., dan Andriana, D (2008) bahwa kualitas mencerminkan semua dimensi penawaran produk yang menghasilkan manfaat (benefits) bagi pelanggan.

Menurut Kotler, P., dan Armstrong, G (2009) menjelaskan bahwa Kualitas produk adalah karakteristik suatu produk atau jasa yang menunjang kemampuannya untuk memuaskan kebutuhan pelanggan. Sedangkan menurut Kotler, P., dan Keller, K.L (2009) mengatakan bahwa kualitas produk adalah kemamapuan suatu barang untuk memberikan hasil atau kinerja yang sesuai bahkan melebihi dari apa yang diinginkan pelanggan.

Menurut Lupioyadi, R., dan Hamdani, A (2010) mengatakan bahwa kualitas produk adalah proses produksi suatu barang dimana kualitas produk yang diberikan oleh perusahaan dapat menciptakan suatu persepsi positif dari pelanggan terhadap perusahaan dan menghasilkan suatu kepuasan serta loyalitas pelanggan.

Menurut Garvin dalam Gaspersz, V (2001) ada delapan dimensi yang dapat digunakan untuk menentukan karakteristik produk yaitu : 1) Performance (performansi); 2) Features (Fitur); 3) Reliability (Keandalan); 4) Comformance (Konformansi); 5) Durability (Daya tahan); 6) Serviceability (Kemampuan pelayanan); 7) Aesthetic (Estetika); dan 8) Preceived Quality (Kualitas yang dirasa)

Citra merek adalah persepsi dan keyakinan yang dilakukan oleh konsumen, seperti tercermin dalam asosiasi yang terjadi dalam memori konsumen (Kotler, P., dan Keller, K.L., 2009). Sedangkan menurut Johannes, Roza, S., dan Ilunitedra (2015) Citra merek adalah apa yang dipersepsikan oleh konsumen mengenai sebuah merek. Hal ini menyangkut bagaimana seorang konsumen menggambarkan apa yang mereka rasakan terhadap merek. 
Keller, K.L (2008) menyatakan bahwa citra merek adalah persepsi tentang merek yang digambarkan oleh asosiasi merek yang ada dalam ingatan konsumen. Selanjutnya menurut Xian, Gou Li, dkk (2011) menyatakan bahwa "The user image refers to whether the brand personality is congruent with the consumers." Citra pemakai mengacu pada apakah kepribadian merek sesuai dengan konsumen.

Kotler dalam Alma, B (2013) menjelaskan bahwa "image is the set of beliefs, ideas and impressions that a person holds regarding an object, people attitude and actions towards an object are highly conditioned by that object's image. Citra adalah sebuah seperangkat keyakinan, ide dan kesan bahwa seseorang memegang kepercayaan kepada sesuatu objek (merek), sikap seseorang dan tindakan berkelanjutan terhadap objek ditentukan kondisi yang tinggi oleh citra objek (merek) tersebut.

Lebih lanjut Kotler dalam Alma, B (2013) menjelaskan bahwa citra merek adalah suatu simbol rumit yang mempunyai enam tingkat makna atau pengertian yaitu : 1) Attributes (Atribut); 2) Benefit (Manfaat); 3) Value (Nilai); 4) Culture (Budaya); 5) Personality (Kepribadiaan); dan 6) User (Pemakai).

Loyalitas adalah konsep yang subjektif, konsep yang paling baik didefinisi pelanggan itu sendiri, dan memiliki tingkatan-tingkatan loyalitas (Barnes, C., 2009). Menurut Griffin, J (2005) "loyalitas adalah komitmen pelanggan bertahan secara mendalam untuk berlangganan kembali atau melakukan pembelian ulang produk/jasa terpilih secara konsisten dimasa yang akan datang, meskipun pengaruh situasi dan usaha-usaha pemasaran mempunyai potensi untuk menyebabkan perubahan prilaku".

Loyalitas pelanggan merupakan komitmen pelanggan untuk bertahan secara mendalam untuk melakukan pembelian ulang atau berlangganan kembali produk atau jasa terpilih secara konsisten di masa yang akan datang, meskipun pengaruh situasi dan usaha-usaha pemasarab mempunyai potensi untuk menyebabkan perubahan perilaku (Oliver dalam Yuniarti, Y., dan Ariyanto, A., 2018). Sedangkan menurut Barnes, C (2009) "Pelanggan dalam berbisnis akan mendefinisi loyalitas dalam berbagai cara yang berbeda. Sering kali lamanya pelanggan berbisnis dengan perusahaan tersebut dan pembelian secara berulang, digunakan sebagai ukuran loyalitas. Dalam hal ini, loyalitas disamakan atau bahkan didefinisi sebagai presentase dari total pembelanjaan dalam katagori produk atau jasa".

Pearson dalam Akbar, M.M., dan Parves, N (2009) mendefinisikan pelanggan loyal sebagai himpunan pelanggan yang memiliki sikap mendukung terhadap perusahaan, berkomitmen untuk membeli kembali produk atau jasa perusahaan, dan merekomendasikan produk atau jasa perusahaan kepada orang lain. Dalton dalam Soegoto, H (2010) menyatakan bahwa pelanggan akan setia kepada orang-orang yang membantu mereka dalam menyelesaikan masalah melampaui apa yang pelanggan harapkan. Loyalitas pelanggan terjadi ketika ada pembelian berulang oleh pelanggan yang sama dan kesediaan mereka untuk merekomendasikan produk kepada pelanggan lain tanpa imbalan langsung dan akhirnya penggunaan berulang tersebut akan berdampak pada hasil keuangan yang terukur (Al-Rousan, Ramzi, M., and Mohamed, B., 2010).

Menurut Griffin, J (2005) menyatakan bahwa ada empat indikator untuk mengukur loyalitas pelanggan sebagai berikut: 1) Melakukan pembelian berulang secara teratur; 2) Membeli antarlini produk dan jasa; 3) Mereferensikan kepada orang lain; dan 4) Menunjukkan kekebalan terhadap tarikan dari pesaing-pesaing.

\section{Kerangka pemikiran}

Kualitas produk (quality product) adalah salah satu sarana positioning utama pemasaran. Kualitas mempunyai dampak langsung pada kinerja produk dan jasa; 
kualitas berhubungan erat dengan nilai dan kepuasan pelanggan. Kualitas produk yang unggul dapat meningkatkan loyalitas pelanggan (Kotler, P., dan Amstrong, G., 2009).

Adanya hubungan kualitas produk terhadap loyalitas pelanggan dikemukakan oleh Kotler, P., dan Amstrong, G (2009) dimana Kualitas produk yang unggul dapat meningkatkan loyalitas pelanggan. Selain itu beberapa penelitian yang telah dilakukan sebelumnya juga mengemukakan jika kualitas produk yang baik akan mampu meningkatkan loyalitas pelanggan, diantaranya yaitu penelitian yang dilakukan oleh Andreas, C (2016), Irawan, D., dan Japarianto, E (2013), dan Fauzi'ah, S (2014).

Sedangkan hubungan antara citra merek dengan loyalitas pelanggan Rangkuti, $\mathrm{F}$ (2002) mengatakan apabila konsumen beranggapan bahwa merek tertentu secara fisik berbeda dari merek pesaing, citra merek tersebut akan melekat secara terus menerus sehingga dapat membentuk kesetiaan merek tertentu yang disebut dengan loyalitas merek. Selain itu beberapa penelitian yang telah dilakukan sebelumnya juga mengemukakan jika citra merek dapat meningkatkan loyalitas pelanggan, diantaranya yaitu penelitian yang dilakukan oleh Tomida, M (2016), Wicaksono, R.K (2014), dan Sastha, G.A.W.N., dan Wardhana, A (2016).

Berdasarkan tujuan penelitian, kajian pustaka, penelitian terdahulu dan hubungan antar variabel maka kerangka analisis dalam penelitian ini disajikan dalam bentuk Gambar 1 Dimana variabel kualitas produk dan citra merek merupakan variabel independent dan variabel loyalitas pelanggan sebagai variabel dependent.

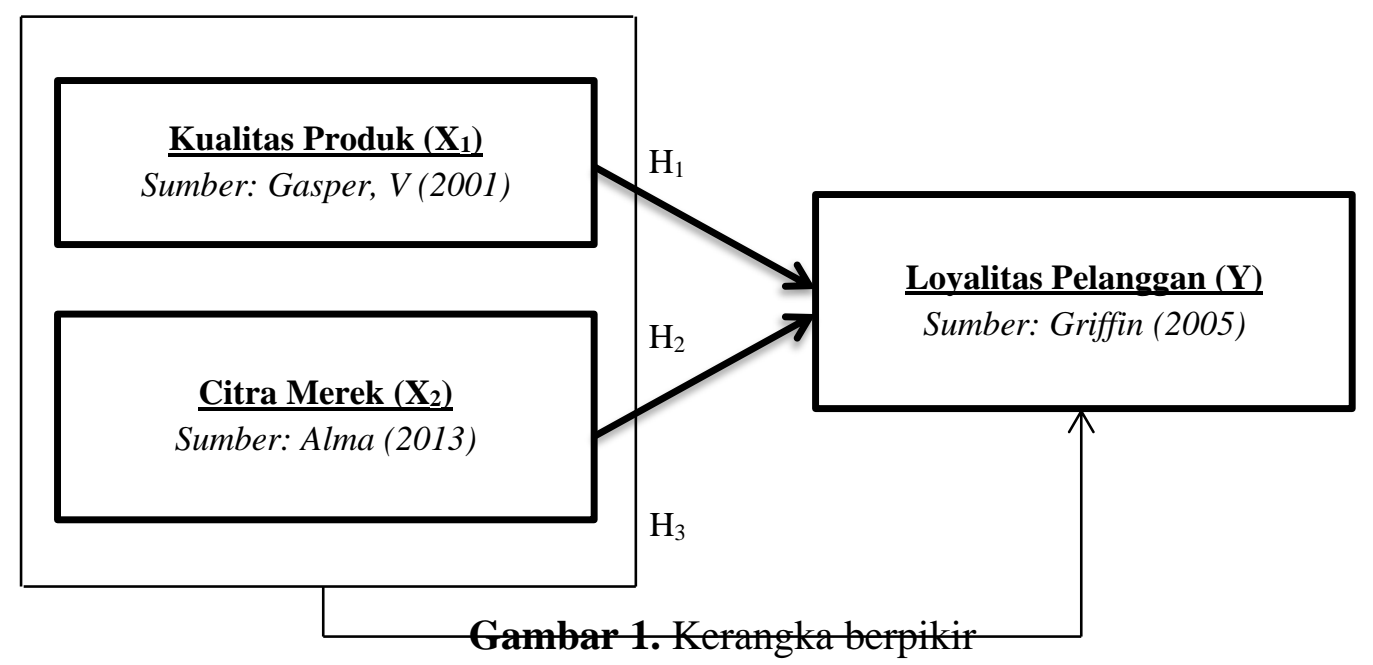

\section{Hipotesis}

Berdasarkan permasalahan yang diteliti, maka ditarik suatu hipotesis sebagai berikut:

$\mathrm{H}_{0}$ : Kualitas produk secara parsial tidak berpengaruh terhadap loyalitas pelanggan.

$\mathrm{H}_{1}$ : Kualitas produk secara parsial berpengaruh terhadap loyalitas pelanggan.

$\mathrm{H}_{0}$ : Citra merek secara parsial tidak berpengaruh terhadap loyalitas pelanggan.

$\mathrm{H}_{1}$ : Citra merek secara parsial berpengaruh terhadap loyalitas pelanggan.

$\mathrm{H}_{0}$ : Kualitas produk dan citra merek secara simultan tidak berpengaruh terhadap loyalitas pelanggan.

$\mathrm{H}_{1}$ : Kualitas produk dan citra merek secara simultan berpengaruh terhadap loyalitas pelanggan. 


\section{METODE}

\section{Populasi dan sampel}

Populasi dalam penelitian ini adalah konsumen pengguna OPPO Smartphone di Jambi sebanyak 12.598 konsumen berdasarkan data penjualan pada AK Phone Kota Jambi. Ukuran atau jumlah sampel dalam penelitian ini ditentukan berdasarkan teori yang dikembangkan oleh Slovin, Umar, H (2008). Berdasarkan rumus penentuan jumlah sampel dari Slovin di atas didapat jumlah sampelnya (n) sebanyak 99,21 di bulatkan menjadi 99 dengan nilai $\mathrm{e}=10 \%$.

\section{Sumber data}

Data primer dikumpulkan dengan menggunakan kuesioner yang bersifat tertutup, sedangkan data sekunder diperoleh dari berbagai sumber termasuk dari perusahaan yang dijadikan sampel

\section{Analisis dan alat analisis data}

Dari hasil kuesioner, data menggunakan dsitribusi frekuensi untuk memperoleh nilai rata-rata. Selanjutnya data dianalisi menggunakan regresi linear berganda.

\section{Variabel penelitian}

Variabel kualitas produk $\left(\mathrm{X}_{1}\right)$ dijadikan sebagai variable independent pertama, dengan sub variable Performance (Tampilan), Features (Fitur), Reability (Kehandalan), Conformance (Konformansi), Durability (Daya tahan), Serviceability (Servis), Aesthetic (estetika), dan Perceived quality (Kualitas yang dirasa). Variabel citra merek $\left(\mathrm{X}_{2}\right)$ dijadikan sebagai variable independent kedua, dengan sub variable Atributes (Atribut), Value (Nilai), Culture (Budaya), Personality (Kepribadian), dan User (Pemakai). Kemudian untuk variable dependentnya adalah loyalitas pelanggan $(\mathrm{Y})$.

\section{HASIL DAN PEMBAHASAN}

\section{Karakteristik responden}

Karakteristik responden penelitian dibagi menjadi 5 jenis, yaitu berdasakan jenis kelamin, usia responden, pekerjaan, lama menggunakan produk dan penghasilan responden. Responden yang berjenis kelamin pria adalah yang terbanyak yakni 57 persen. Sedangkan sisanya adalah responden berjenis kelamin perempuan dengan yang berjumlah 43 persen. Berdasakan pengelompokan usia didominasi oleh kelompok usia 26 - 35 tahun dengan persentase sebesar 52 persen, kemudian untuk kelompok usia 18 25 tahun sebesar 27 persen, kelompok usia 36 - 45 tahun sebesar 18 persen, dan untuk kelompok usia 46 - 55 tahun sebesar 3 persen. Kemudian berdasarkan karakteristik pekerjaan didominasi oleh PNS yaitu sebanyak 33 persen,Wiraswastas sebanyak 31 persen, Mahasiswa/I sebanyak 22 persen, dan Karyawan swasta sebesar 14 persen. Selanjutnya karakteristik responden berdasarkan lama menggunakan Oppo Smartphone yang terjaring untuk selama 1 tahun sebanyak 14 Persen, 2 tahun sebanyak 19 persen, 3 tahun sebanyak 37 persen, 4 tahun sebanyak 18 persen, dan $>4$ tahun sebanyak 12 persen. Dan untuk karakteristik responden berdasarkan penghasil per bulan yang terjaring dalam penelitian ini didominasi oleh kelompok dengan peghasilan $3-4 \mathrm{Jt}$ Rupiah yaitu sebanyak 37 persen, penghasilan < 2 Jt Rupiah sebanyak 4 persen, 
penghasilan 2 - 3 Jt Rupiah sebanyak 19 persen, penghasilan 4 - 5 Jt Rupiah sebanyak 28 persen, dan penghasilan $>5$ Jt Rupiah sebanyak 28 persen.

\section{Nilai dan rata-rata variabel penelitian}

Hasil deskriptif kualitas produk dari enam belas pernyataan yang diajukan diperoleh skor rata-rata sebesar 3,67. Apabila dilihat pada Kriteria presentase skor responden terhadap skor ideal pada Tabel 3.2 tampak bahwasanya variabel kualitas produk termasuk pada range 3,4 - 4,1 berada pada kriteria baik. Yang menjelaskan bahwasanya pelanggan setuju jika kualitas produk Oppo Smartphone dinilai memiliki kualitas yang baik oleh responden. Baik itu dari tampilannya, fitur, kehandalan, konformansi, daya tahan, servis, estetika maupun kualitas yang dirasa oleh responden.

Hasil deskriptif citra merek dari tiga belas pernyataan yang diajukan diperoleh skor rata-rata sebesar 3,75. Apabila dilihat pada Kriteria presentase skor responden terhadap skor ideal pada Tabel 3.2 tampak bahwasanya variabel citra merek termasuk pada range 3,4 - 4,1 berada pada kriteria baik. Yang menjelaskan bahwasanya pelanggan setuju jika Oppo Smartphone memiliki citra yang baik di persepsi responden. Baik itu dari atribut, nilai, budaya, kepribadian dan pemakai.

Hasil deskriptif loyalitas pelanggan dari epat pernyataan yang diajukan diperoleh skor rata-rata sebesar 3,68. Apabila dilihat pada kriteria presentase skor responden terhadap skor ideal pada Tabel 3.2 tampak bahwasanya variabel loyalitas pelanggan termasuk pada range 3,4 - 4,1 berada pada kriteria Tinggi. Yang menjelaskan bahwasanya responden memiliki loyalitas yang tinggi terhadap produk Oppo Smartphone. Artinya responden senantiasa mengikuti perkembangan dan membeli produk Oppo Smarphone, senantiasa mengikuti perkembangan produk Oppo Smarphone, senantiasa akan mereferensikan Oppo Smarphone kepada orang lain, serta senantiasa akan selalu menggunakan Oppo Smarphone dan tidak akan pindah ke Smarphone lain.

\section{Hasil uji statistik}

Persyaratan untuk menggunakan analisis regresi berganda adalah terpenuhinya asumsi klasik. Untuk mendapatkan nilai pemeriksa yang efisien dan tidak bias atau BLUE (Best Linear Unbias Estimator) dari satu persamaan regresi berganda dengan metode kuadrat terkecil (least square), maka perlu dilakukan pengujian untuk mengetahui model regresi yang dihasilkan memenuhi persyaratan asumsi klasik. Dalam penelitian ini akan di kemukakan uji asumsi klasik yang umum digunakan, yaitu Uji Normalitas Uji Muktikolinearitas dan Uji Heterokedastisitas.

Dari hasil uji yang dilakukan dengan menggunkan bantuan SPSS 21.0 sebagai alat bantu dalam penelitian ini diperoleh hasil bahwasanya data dalam penelitian ini berdistribusi normal, hal ini dibuktikan dari hasil nilai signifikansi (Asymp. Sig. 2tailed) lebih besar dari 0,05 , yaitu $(0,454>0,05)$ sehingga dapat disimpulkan bahwa data dalam penelitian ini berdistribusi normal.

Kemudian dari hasil uji multikolinearitas diketahui bahwasanya hasil perhitungan nilai Tolerance menunjukan tidak ada variabel independent yang memiliki nilai Tolerance kurang dari 0.10 , yang berarti tidak ada korelasi antar variabel independent. Selain itu pula hasil perhitungan nilai Variance Inflation Factor (VIF) juga menunjukan hal yang sama tidak ada satu variabel independent yang memiliki nilai VIF lebih dari 10. Jadi dapat disimpulkan bahwa tidak terjadi multikolinearitas antar variabel Independent dalam model regresi. 
Selanjutnya dari hasil uji heterokedastisitas diketahui scatterplots terlihat bahwa titik-titik menyebar secara acak serta tresebar baik diatas maupun dibawah angka 0 pada sumbu Y. hal ini dapat disimpulkan bahwa tidak terjadi heterokedastisitas pada model regresi, sehingga model regresi layak dipakai untuk memprediksi Penggunaan jasa akomodasi berdasarkan masukan variabel independent.

Berdasarkan dari hasil uji asumsi tersebut maka telah terpenuhinya Persyaratan untuk menggunakan analisis regresi berganda.

\section{Statistik uji}

Analisis regresi digunakan untuk melihat pengaruh variabel bebas terhadap variabel terikat. Berdasarkan estimasi regresi berganda dengan program SPSS 21.0 diperoleh hasil seperti Tabel 1 dibawah ini.

Tabel 1 Ringkasan hasil uji statistik

\begin{tabular}{clcc}
\hline \multirow{2}{*}{ No } & \multicolumn{1}{c}{ Ukuran Statistik } & $\begin{array}{c}\text { Nilai Hitung dan Koefisien } \\
\text { Regresi }\end{array}$ & \multirow{2}{*}{$\mathbf{P}_{\text {value }}$} \\
\hline 1 & Uji F & 80.532 & $0.000^{* *}$ \\
& Uji t (koefisien) & & $0.000^{* *}$ \\
& X1_Kualitas_Produk & 7.182 & $0.000^{* *}$ \\
& X2_Citra_Merek & 3.784 & \\
2 & Koefisien Determinasi R & 0,624 & \\
\hline
\end{tabular}

Sumber: Data diolah, 2018

Dengan demikian dapat disusun hasil regresi sebagai berikut.

$Y=0,415+0,157 . X_{1}+0,123 . X_{2}+e$

Berdasarkan $\mathrm{P}_{\text {value }}$ semua koefisien variable memiliki hubungan yang signifikan. Secara simultan, persamaan regresi diatas dapat menjelaskan variasi loyalitas pelanggan sebesar $62,4 \%$, sedangkan sisanya sebesar 37,6\% dipengaruhi oleh variabel lain yang tidak dimasukan dalam model ini.

Dari hasil uji regresi pada Tabel 1 diatas dengan menggunakan SPSS 21.0 diperoleh angka t hitung variabel kualitas produk $\left(\mathrm{X}_{1}\right)$ sebesar 7.182 , dengan nilai signifikansi sebesar 0,000, dikarenakan angka taraf signifikansi $<0.05(0.000<0.05)$ maka dapat disimpulkan bahwa kualitas produk $\left(\mathrm{X}_{1}\right)$ berpengaruh terhadap loyalitas pelanggan $(\mathrm{Y})$. Artinya terdapat hubungan linier antara kualitas produk $\left(\mathrm{X}_{1}\right)$ dengan loyalitas pelanggan $(\mathrm{Y})$.

Hasil penelitian ini menunjukan hasil yang sama dengan penelitian yang dilakukan oleh Andreas, C (2016), Irawan, D., dan Japarianto, E (2013), dan Fauzi'ah, S (2014) dimana hasil penelitiannya mengemukakan jika kualitas produk yang baik akan mampu meningkatkan loyalitas pelanggan.

Setiap orang memiliki cara pandang dan standar yang berbeda didalam menilai barang atau jasa yang ditawarkan. Oleh karena itu dalam mengelola kualitas suatu produk harus sesuai dengan kegunaan yang diinginkan konsumen (Wahid, M.A., 2014). Menurut Kotler, P., dan Amstrong, G (2009) kualitas produk (quality product) adalah salah satu sarana positioning utama pemasaran. Kualitas mempunyai dampak langsung pada kinerja produk dan jasa; kualitas berhubungan erat dengan nilai dan kepuasan pelanggan. Kualitas produk yang baik pada dasarnya akan memberikan pengaruh positif terhadap perusahaan, karena konsumen akan memilih produk dengan kualitas yang terbaik. Kemampuan produk dalam memberikan kualitas terbaik akan menguatkan 
kedudukan atau posisi produk dalam benak konsumen pada pembelian diwaktu yang akan datang. Kualitas yang baik memungkinkan adanya kepuasan konsumen dan akan menarik konsumen baru, sehingga diharapkan akan membuat konsumen loyal pada akhirnya (Fauzi'ah, S, 2014).

Dari hasil uji regresi pada Tabel 1 diatas dengan menggunakan SPSS 21.0 diperoleh angka t hitung variabel citra merek $\left(\mathrm{X}_{2}\right)$ sebesar 3.784, dengan nilai signifikansi sebesar 0,000, dikarenakan angka taraf signifikansi $<0.05(0.000<0.05)$ maka dapat disimpulkan bahwa citra merek $\left(\mathrm{X}_{2}\right)$ berpengaruh terhadap loyalitas pelanggan $(\mathrm{Y})$. Artinya terdapat hubungan linier antara citra merek $\left(\mathrm{X}_{2}\right)$ dengan loyalitas pelanggan $(\mathrm{Y})$.

Beberapa penelitian yang telah dilakukan sebelumnya juga mengemukakan jika citra merek dapat meningkatkan loyalitas pelanggan, diantaranya yaitu penelitian yang dilakukan oleh Tomida, M (2016), Wicaksono, R.K (2014), dan Sastha, G.A.W.N., dan Wardhana, A (2016).

Citra merupakan sebagai sebuah gambaran yang ada di dalam benak seorang individu Henslowe, P (2000) mengatakan bahwa citra adalah kesan yang diperoleh dari tingkat pengertian dan pengetahuan terhadap fakta mengenai orang lain, produk, atau situasi. Citra terhadap suatu produk tidak dapat dipisahkan dari merek produk tersebut dan juga perusahaan yang mengeluarkan produk merek tersebut kedalam pasar. Semakin baik citra suatu merek dalam benak konsumen maka akan membuat konsumen memiliki ciri-ciri pelanggan yang loyal (Griffin, J., 2005). Selain itu Rangkuti, F (2002) mengatakan apabila konsumen beranggapan bahwa merek tertentu secara fisik berbeda dari merek pesaing, citra merek tersebut akan melekat secara terus menerus sehingga dapat membentuk kesetiaan merek tertentu yang disebut dengan loyalitas merek.

Dari uji Anova atau $F$ test dengan menggunakan SPSS 21.0 didapat $F_{\text {hitung }}$ sebesar 80.532 dengan tingkat probabilitas $p$-value sebesar 0,000, dikarenakan angka taraf signifikansi jauh lebih $<0.05(0.000<0.05)$ oleh karena itu $\mathrm{H}_{0}$ ditolak dan $\mathrm{H}_{1}$ diterima, sehingga dapat disimpulkan bahwa hipotesis nol $\left(\mathrm{H}_{0}\right)$ ditolak dan hipotesis alternatif $\left(\mathrm{H}_{1}\right)$ diterima artinya hal ini membuktikan variabel kualitas produk dan citra merek secara bersama-sama berpengaruh secara signifikan terhadap variabel loyalitas pelanggan.

Hasil penelitian ini menunjukan hasil yang sama dengan penelitian yang dilakukan dengan oleh Andreas, C (2016), Irawan, D., dan Japarianto, E (2013), Fauzi'ah, S (2014), Tomida, M (2016), Wicaksono, R.K (2014), dan Sastha, G.A.W.N., dan Wardhana, A (2016). Dimana hasil penelitiannya mengemukakan kualitas produk dan citra secara bersama-sama berpengaruh terhadap loyalitas pelanggan.

Loyalitas merupakan asset yang sangat berharga bagi setiap perusahaan karena dengan menjadi pelanggan yang loyal mereka memiliki komitmen terhadap merek yang kemudian akan mendatangkan profit bagi perusahaan. Selain itu juga dalam jangka panjang, menjaga pelangga lama lebih mudah ketimbang mencari dan mendapatkan pelanggan baru. Pelanggan yang loyal menurut Griffin, J (2005) melakukan pembelian ulang, membeli dari berbagai lini produk dari suatu merek yang sama, merekomendasikan merek tersebut kepada orang lain, dan juga memiliki kekebalan terhadap penawaran produk pesaing.

\section{KESIMPULAN DAN SARAN}

\section{Kesimpulan}

Kualitas produk memiki pengaruh terhadap loyalitas pelanggan Oppo Smartphone Kota Jambi. 
Citra merek memiki pengaruh terhadap loyalitas pelanggan Oppo Smartphone Kota Jambi. Kualitas produk dan citra merek memberikan pengaruh terhadap loyalitas pelanggan Oppo Smartphone Kota Jambi.

\section{Saran}

Berdasarkan simpulan di atas dapat diajukan saran-saran kepada pihak manajemen perusahaan dan kalangan akademis sebagai berikut:

\section{Bagi perusahaan}

Kedepan hendaknya manajemen mempertimbangkan kualitas produk serta ragam jenis sesuai jenis kegiatan pemakainya sehingga konsumen akan mendapat banyak pilihan produk yang sesuai keinginannya dengan kualitas yang bagus. Hal ini akan menjadikan produk Oppo Smartphone tampak beragam pilihan dan memberikan kesan yang berkualitas.

Kedepan diharapkan perusahaan Oppo dapat terus mengembangkan smartphonenya sehingga memiliki keunggulan dalam setiap aspeknya sehingga menciptakan citra merek yang lebih kuat mengingat persaingan ponsel sekarang ini semakin ketat dan produk yang ada di dalam pasa hampir tidak memiliki perbedaan.

Perusahaan harus terus mempertahankan loyalitas pelanggannya dengan meningkatkan dan memperbanyak informasi dengan fasilitas online agar perusahaan dapat dengan cepat dalam menangani keluhan dan keinginan dari konsumen atau pelanggannya. Selain itu perusahaan juga harus lebih inovatif dalam mengembangkan produknya agar tidak kalah dari kompetitornya, baik itu dari dari tampilannya, fitur, kehandalan, konformansi, daya tahan, servis, estetika maupun kualitasnya.

\section{Bagi kalangan akademis}

Untuk penelitian selanjutnya, peneliti lain harus lebih memperdalam teori-teori yang ada mengenai kualitas produk, citra merek dan juga loyalitas pelanggan, sehingga dapat mendukung hasil penelitian dan mempermudah dalam menganalisis hasil penelitian.

\section{DAFTAR PUSTAKA}

Akbar, M.M., and Parvez, N. (2009). Impact of services quality, trust, and customer satisfaction on customer loyalty, ABAC Journal, 29(1), 24-38.

Alma, B. (2013). Manajemen pemasaran dan pemasaran jasa. Cetakan Kesepuluh. Bandung: Alfabeta.

Al-Rousan, Ramzi, M., and Mohamed, B. (2010). Customer loyalty and the impacts of service quality: the case of five star hotels in Jordan International, Journal of Business and Economic Sciences, 4(7), 1702-1708

Andreas, C. (2016). Pengaruh kualitas produk terhadap loyalitas pelanggan dengan kepuasan sebagai variabel intervening. Jurnal Ilmu dan Riset Manajemen. $5(5), 1-16$

Barnes. (2009). Elemen kepercayaan. Diambil 16 Juni 20167, dari situs World Wide Web: (http://barnes.blogspot.com/2011/04/elemen-kepercayaan.html).

Fauzi'ah, Siti and, Sri Padmantyo, (2014) Pengaruh kualitas produk terhadap loyalitas pelanggan dengan kepuasan sebagai variabel moderasi. Skripsi thesis, Universitas Muhammadiyah Surakarta.

Gasper, V. (2001). Total quality management. Jakarta: Gramedia Pustaka Utama.

Griffin, J. (2005). Customer loyalty: menumbuhkan dan mempertahankan kesetiaan pelanggan. Jakarta: Erlangga.

Henslowe, P. (2000). The art and science of public relations. new delhi; crest publishing house. New Delhi: Crest Publishing House. 
Irawan, D., dan Japarianto, E. (2013). Analisa pengaruh kualitas produk terhadap loyalitas melalui kepuasan sebagai variabel intervening pada pelanggan restoran POR KEE Surabaya. Jurnal Manajemen Pemasaran. Vol. 1, No. 2.

Johannes, Roza, S., dan Ilunitedra. (2015). Pengaruh green product terhadap brand image produk air minum dalam Kemasan Merek Aqua. Digest Marketing, Vol 1, No. 1 .

Kotler, P \& Keller, K.L. (2009). Manajemen pemasaran, Edisi 12, Jilid 1 \&2, Terjemahan Benyamen Molan. Jakarta: PT.Indah.

Kotler, P dan Amstrong, G. (2009). Prinsip-prinsip pemasaran. Alih Bahasa: Bob Sabran, MM. Edisi 12 jilid 1 dan 2. Jakarta: Erlangga

Lupioyadi, R., dan Hamdani, A. (2010). Bauran pemasaran barang vs jasa. Jakarta: Salemba Empat.

Rangkuti, F. (2002). The power of brand: teknik mengelola brand equity dan strategi pengembangan merek + analisis kasus dengan SPSS. Jakarta: PT. Gramedia Pustaka Utama.

Sastha, G.A.W.N., dan Wardhana, A. (2016). Pegaruh citra merek terhadap loyalitas pelanggan (studi pada pelanggan kartu simpati di Kota Denpasar). e-Proceeding of Management. Vol. 3, No. 2.

Soegoto, H. (2010). Pengaruh nilai dan kepercayaan loyalitas nasabah prioritas. Majalah Ilmiah Unikom, Vol. 7 No. 2.

Supranto dan Limakrisna. (2011). Perilaku konsumen \& strategi pemasaran. Edisi 2. Jakarta: Mitra Wacana Media.

Tjiptono, F., Candra, G,. dan Andriana, D. (2008). Pemasaran strategik. Yogyakarta: Andi

Tomida, M. (2016). Pengaruh harga dan citra merek terhadap loyalitas pelanggan produk footwear yongki komaladi. Jurnal Ilmu dan Riset Manajemen. 5(7), 1-15

Umar, H. (2008). Metode riset bisnis: dilengkapi contoh proposal dan riset bidang manajemen dan akuntansi. Jakarta: Gramedia Pustaka Utama.

Wahid, M.A. (2014). Analisis pengaruh kualitas produk terhadap keputusan pembelian melalui citra merek dan nilai pelanggan (studi pada pengguna Motor Matik Suzuki NEX FI).

Wicaksono, R.K. (2014). Pengaruh citra merek terhadap loyalitas konsumen Coca Cola (Studi Pada Konsumen Coca Cola di Kota Malang).

Xian, Gou Li, dkk. (2011). Corporate, product, and user-image dimensions and purchase intentions. Journal of Computers. 6(9).

Yuniarti, Y., dan Ariyanto, A. (2018). Pengaruh servicecape terhadap loyalitas pelanggan telkomsel. Jurnal Digest Marketing, 3(1). 